\title{
COMUNICAÇÃO
}

\section{OBTENÇ̃̃O DE ANTICORPOS POLICLONAIS CONTRA PROTEÍNAS PRESENTES EM PLANTAS AFETADAS PELA ANOMALIA DECLÍNIO DOS CITROS ${ }^{1}$}

\author{
Production of antibodies against proteins expressed in plants affected by citrus blight \\ Sanzio Carvalho Lima Barrios ${ }^{2}$, Juliana Erika Teixeira ${ }^{3}$, Sebastião Márcio de Azevedo 4 , \\ Magnólia de Araújo Campos ${ }^{5}$, Luciano Vilela Paiva ${ }^{6}$
}

\begin{abstract}
RESUMO
O declínio dos citros, uma anomalia de etiologia desconhecida, continua sendo um dos entraves para o setor citrícola, uma vez que não existem medidas de prevenção e controle para as plantas acometidas pela anomalia. Para a caracterização e estudo da anomalia, muita ênfase tem sido dada à mudança na expressão gênica de plantas afetadas, que culmina no acúmulo de proteínas. Proteínas totais extraídas dos vasos do xilema de raízes de plantas afetadas pela anomalia, quando separadas por eletroforese no sistema SDS-PAGE $12,5 \%$, apresentam um perfil eletroforético contendo proteínas com massas moleculares de cerca de $21,23,31$ e $42 \mathrm{kDa}$, sendo que plantas consideradas sadias apresentam proteínas de 21, 31 e $42 \mathrm{kDa}$. Com este trabalho objetivou-se obter anticorpos contra essas proteínas, bem como a titulação adequada para os mesmos. Duas inoculações subcutâneas foram realizadas em coelhos, espaçadas de 15 dias, ambas usando cerca de $120 \mu \mathrm{g}$ de proteína isolada, sendo que cada coelho recebeu uma proteína específica, visando à produção de anticorpos. A primeira sangria foi realizada aos 21 dias após a primeira inoculação e as demais semanalmente. A técnica Western Blotting foi realizada para a confirmação da especificidade dos anticorpos, bem como para determinação das respectivas titulações. $\mathrm{O}$ título 1:1500 foi aquele que proporcionou maior especificidade para as proteínas de 21, 23 e $31 \mathrm{kDa}$. Para a proteína de $42 \mathrm{kDa}$ a melhor titulação foi de 1:3000. Estes anticorpos poderão ser utilizados em estudos para caracterização dessas proteínas.
\end{abstract}

Termos para indexação: Declínio dos citros, proteína, anticorpos policlonais.

\begin{abstract}
Citrus blight, an abnormality of unknown etiology, is a major problem in citrus production, since there are no prevention and control measures to be taken. In order to characterize this abnormality, changes in genetic expression of the affected plants have exhaustedly been studied. Crude proteec extract obtained from the root xylem of the abnormal plants, when separated by SDS-PAGE $12,5 \%$, display a profile with $21,23,31$ and $42 \mathrm{kDa}$ proteins. This work aimed the production of antibodies against those proteins, as well as their ideal dilution for use. Two subcutaneous inoculations were done in rabbits, within a 15-day interval, both with approximately $120 \mathrm{mg}$ of the isolated protein, with each rabbit receiving shots with a specific protein, for the production of the antibodies. A First bleeding was performed 21 days after the first inoculation and afterwards, weekly. Western blotting was carried out to confirm the presence of the antibodies and their respective dilutions. The 1:1500 dilution provided the best specificity for the 21 , 23 and $31 \mathrm{kDa}$ proteins, whereas for the 26 and $42 \mathrm{kDa}$ proteins, the best dilution was at 1:3000.
\end{abstract}

Index terms: Citrus blight; protein; antibody.

\section{(Recebido para publicação em 2 de junho de 2005 e aprovado em 8 de novembro de 2005)}

O Brasil é o maior produtor de citros e exportador de suco de laranja concentrado congelado (SLCC) do mundo. No entanto, a produção ainda é baixa devido a problemas fitossanitários, dentre eles se enquadra o Declínio dos Citros . Embora o declínio dos citros tenha sido descrito há mais de 100 anos atrás, continua sendo o responsável pela eliminação de plantas e prejuízos na citricultura. O declínio dos citros no Brasil despertou inicialmente a atenção de citricultores e técnicos da Secretaria de Agricultura e Abastecimento do Estado de São Paulo, no fim da década de 1970, sendo considerado do mesmo grupo da doença "blight". Foi posteriormente constatado nos Estados da Bahia, de Sergipe, de Minas Gerais, do Rio de Janeiro e de Goiás. Estima-se ter havido uma perda da ordem de várias dezenas de milhões de plantas cítricas, desde sua constatação em 1979 (COSTA

\footnotetext{
${ }_{1}$ Projeto financiado pelo CNPq, desenvolvido no Laboratório Central de Biologia Molecular LCBM/UFLA.

${ }^{2}$ Bolsista Iniciação Científica CNPq/PIBIC, 5ำ módulo Agronomia - Universidade Federal de Lavras/UFLA - Cx P. 3037 - $37200-000$ - Lavras, MG sanzio@ufla.br

${ }^{3}$ Engenheira Agrônoma, mestranda em Genética e Melhoramento de Plantas - Departamento de Biologia - Universidade Federal de Lavras/UFLA Cx P. 3037 - 37200-000 - Lavras, MG.

${ }^{4}$ Engenheiro Agrônomo, Dr., pesquisador Sakata seeds.

${ }^{5}$ Bióloga Molecular, Dra., bolsista Recém Doutora/CNPq/LCBM/UFLA.

${ }^{6}$ Engenheiro Agrônomo, Dr., Professor Adjunto Departamento de Química da Universidade Federal de Lavras/UFLA - Cx P. 3037 - $37200-000$ Lavras, MG.
} 
et al., 1998). Esse prejuízo é devido à ausência de medidas profiláticas (etiologia ainda é desconhecida), e à manifestação tardia dos seus sintomas, que só aparecem após três anos, quando as plantas entram em produção. As plantas com declínio dos citros podem ser afetadas parcialmente ou integralmente, quando estão no estádio mais avançado da doença. Os sintomas são também acompanhados de algumas alterações no balanço de nutrientes (GIROTO, 1990; PAIVA, 1993; TAVARES, 1987), sendo a mais proeminente, a redistribuição de Zn (ALBRIGO \& YOUNG, 1981; TAYLOR et al., 1988). As plantas afetadas raramente morrem, mas apresentam uma expressiva redução na produção, no tamanho dos frutos e na longevidade. Internamente, nos vasos do xilema, essas plantas apresentam acima da região da enxertia obstruções amorfas, as quais reduzem a translocação hídrica nestes tecidos (BERETTA \& ROSSETTI, 1988; BRLANSKY et al., 1984).

Aparentemente, todas as combinações enxerto/ porta-enxerto são susceptíveis ao declínio, mas o nível de incidência varia com o tipo de porta-enxerto. Os portaenxertos laranja 'Doce', laranja 'Azeda' e tangerina 'Cleopatra' possuem uma certa tolerância, visto que a incidência da doença ocorre em menor quantidade e os sintomas visuais normalmente aparecem em plantas com mais de 15 anos de idade (BERETTA \& LEFEVRE, 1986). Já o limoeiro 'Cravo', provavelmente por ser o porta-enxerto mais utilizado na citricultura nacional, se revela como o mais susceptível ao declínio (BERETTA \& ROSSETTI, 1990).

Um teste diagnóstico bastante utilizado para distingüir plantas com declínio dos citros é o teste de absorção de água. Nesse teste, um orifício é feito com auxílio de uma seringa, acima da região da enxertia, onde tenta-se injetar $10 \mathrm{~mL}$ de água durante 20 segundos (LEE et al., 1984). Uma vez que plantas com declínio dos citros, possuem obstruções amorfas e filamentosas nos vasos do xilema, a absorção de água é nula ou reduzida, enquanto que em plantas sadias a absorção é total. A única prática recomendada, quando diagnosticada a anomalia, é a eliminação da planta, uma vez que ela passa a produzir em níveis abaixo do economicamente viável.

Analisando o perfil protéico de extratos de xilema de raízes do limoeiro 'Cravo', de plantas com declínio dos citros sob condições edafoclimáticas do Brasil, verificouse a presença de proteínas com massas moleculares de aproximadamente 21, 23, 26, 31 e $42 \mathrm{kDa}$, sendo as de $23 \mathrm{e}$ $26 \mathrm{kDa}$ consideradas específicas de plantas com declínio dos citros (PAIVA, 1993).

Para o presente trabalho, foram coletadas raízes do porta-enxerto Citrus limonia Osbeck cv. Cravo com aproximadamente 15 a 16 anos de idade, de mesmo pomar comercial, localizado no Estado de São Paulo. Para distingüir plantas sadias de plantas afetadas pelo declínio dos citros utilizaram-se a análise visual e o método de injeção de água no tronco sob pressão, usando seringa (LEE et al., 1984). Amostras de raízes com 1 a $2 \mathrm{~cm}$ de diâmetro foram coletadas de plantas com declínio, embaladas em papel umedecido e colocadas em caixa de isopor para transporte. No laboratório Central de Biologia Molecular da UFLA, as amostras foram mantidas a $4^{\circ} \mathrm{C}$ até a extração das proteínas.

Para a extração das proteínas presentes no xilema, as amostras de raízes foram cortadas com aproximadamente $10 \mathrm{~cm}$ de comprimento e a casca de suas extremidades removidas. Proteínas totais solúveis foram extraídas usando o tampão PBS ( $0,8 \%$ de $\mathrm{NaCl} ; 0,02 \%$ de $\mathrm{KH}_{2} \mathrm{PO}_{4}$; $0,29 \%$ de $\mathrm{Na}_{2} \mathrm{HPO}_{4} \cdot 12 \mathrm{H}_{2} \mathrm{O} ; 0,02 \%$ de $\left.\mathrm{KCl} ; \mathrm{pH} 7,4\right)$, acrescido de $1 \%$ do agente redutor beta-mercaptoetanol, de acordo com a metodologia descrita por Paiva (1993). As proteínas foram separadas por eletroforese em géis desnaturantes, contendo $12,5 \%$ de poliacrilamida e $0,1 \%$ de sódio dodecil sulfato (SDS-PAGE), sob uma voltagem constante de 100V, durante duas horas e trinta minutos. A coloração dos géis foi feita em solução de Comassie blue ( $0,5 \%$ de comassie blue R-250; 50\% de etanol; $10 \%$ de ácido acético) e a descoloração em solução contendo $10 \%$ de ácido acético e 5\% de etanol. O perfil protéico das proteínas extraídas dos vasos lenhosos de raízes de plantas sadias e afetadas pela anomalia declínio dos citros, encontra-se na Figura 1.

No extrato de plantas doentes ( 1 a 3 ) estão presentes proteínas com massas moleculares de aproximadamente 21, 23, 31 e $42 \mathrm{kDa}$, sendo que em plantas consideradas sadias (4 a 6), estão presentes proteínas com massas moleculares de aproximadamente 21,31 e $42 \mathrm{kDa}$ (4 e 6) e de 21, 23, 31 e $42 \mathrm{kDa}$ (5). A ausência, em plantas doentes, da proteína de $26 \mathrm{kDa}$ pode ser explicada pela quantidade insuficiente desta proteína para visualização no gel. Estes dados diferem dos obtidos por outros autores. Paiva (1993) relacionou proteínas de 23 e $26 \mathrm{kDa}$ como sendo específicas de plantas doentes. Uma possível explicação para a proteína de $23 \mathrm{kDa}$, seria que uma planta considerada como sadia, pelos sintomas visuais e teste de absorção de água, na verdade pode ser uma planta doente assintomática, no início da doença.

Com o presente trabalho, objetivou-se produzir anticorpos policlonais monoespecíficos, em coelho, para todas as proteínas solúveis $(21,23,31$ e $42 \mathrm{kDa})$ presentes em raízes do porta-enxerto Citrus limonia cv. Cravo, visando uma caracterização destas proteínas. 


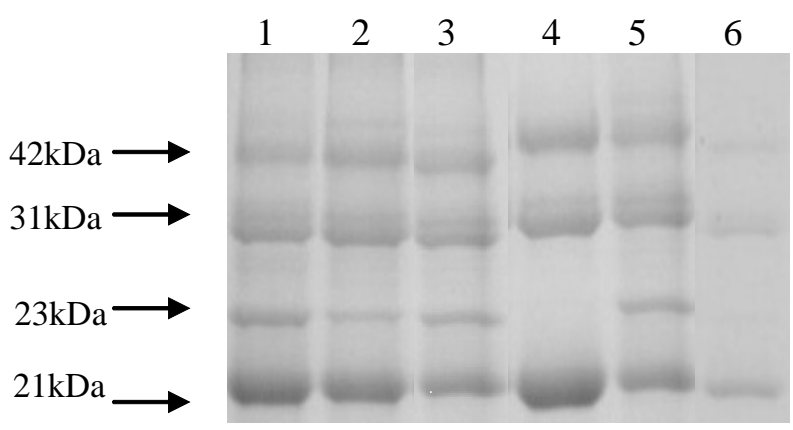

FIGURA 1 - Perfil eletroforético de proteínas solúveis presentes no xilema de raízes de limoeiro 'Cravo', em gel SDSPAGE 12,5\%, classificadas por sintomas visuais e teste de absorção de água como afetadas pela anomalia declínio dos citros (1 a 3) e sadias (4 a 6). Cada poço contêm aproximadamente $7 \mu \mathrm{g}$ de proteína total.

Os anticorpos policlonais monoespecíficos para as proteínas 21, 23, 31 e $42 \mathrm{kDa}$ foram obtidos por meio da imunização em coelhos, de acordo com metodologia descrita por Paiva (1993). As proteínas foram excisadas de região não corada de gel SDS-PAGE, tendo como base uma região do mesmo gel, corada com Comassie blue e o marcador de massa molecular CFA626 (Amersham Pharmacia). Cada proteína excisada do gel foi eletroeluída, congelada, liofilizada, ressuspendida em água e quantificada, usando o método de Bradford (1976). Cada coelho recebeu aproximadamente $120 \mu \mathrm{g}$ de uma determinada proteína.

A determinação do título do anticorpo foi feita com o uso da técnica Western blot. Uma alíquota de $7 \mu \mathrm{g}$ de proteínas solúveis, presente em xilema de raízes de limoeiro 'Cravo', foi usada em cada poço de gel SDS-PAGE e em seguida, o perfil eletroforético foi transferido para uma membrana de nitocelulose (Hybond). A transferência das proteínas para membrana foi feita pelo método de eletrotransferência semi-seco, mantendo as mesmas posições relativas em que se encontravam no gel. Posteriormente, a membrana foi bloqueada por 30 minutos em solução TTBS $(100 \mathrm{~mL}$ de $\mathrm{NaCl} 5 \mathrm{M} ; 20 \mathrm{~mL}$ de Tris $\mathrm{pH}$ 7,5; 1,5 mL de Tween 20; q.s.p 1L), adicionado de $3 \%$ de leite desnatado, sob agitação, para evitar reações inespecíficas. Para a determinação do título dos anticorpos, a membrana foi cortada, de modo que cada fração continha o antígeno imobilizado, a qual foi tratada separadamente com várias diluições do anticorpo primário, produzido em coelho, e incubado à temperatura ambiente, durante uma noite. Em seguida, três lavagens foram realizadas com TTBS, por cinco minutos cada. $\mathrm{O}$ anticorpo secundário foi adicionado e incubado por 2 horas. Novamente foram realizadas três lavagens com TTBS por 5 minutos cada. Ao final, o reagente de coloração foi adicionado, revelando por precipitação de um produto colorido, a ocorrência de reação entre a proteína desejada e o anticorpo específico. O resultado do Western blot pode ser observado na Figura 2.

O título 1:1500 foi aquele em que se visualizou com maior nitidez a reação das proteínas de 21,23 e 31 kDa contra seus respectivos anticorpos, utilizando cerca de $7 \mu \mathrm{g}$ de proteína total/poço. Para a proteína de $42 \mathrm{kDa}$ foi observado a presença de reações inespecíficas na membrana de nitrocelulose, sendo que o título que mais se adequou a situação foi o de 1:3000, utilizando cerca de 1,7 $\mu \mathrm{g}$ de proteína total/poço.

Como pode ser observado na Figura 2, o anticorpo contra a proteína de $42 \mathrm{kDa}$, não apresentou reação específica para com a respectiva proteína. Uma possível explicação para esse fato poderia ser que a proteína em questão, pode apresentar epitopos semelhantes com outras proteínas e por isso o anticorpo detectou mais de uma banda.

Os anticorpos produzidos poderão ser utilizados, num futuro próximo, no desenvolvimento de testes imunológicos adequados para plantas de citros no Brasil, e na caracterização funcional das proteínas encontradas em plantas com a anomalia Declínio dos Citros. Uma das vantagens da diagnose precoce do declínio dos citros é a possibilidade de se desenvolver um programa de monitoramento das plantas infectadas (assintomáticas e/ ou pré-sintomáticas) no pomar. 


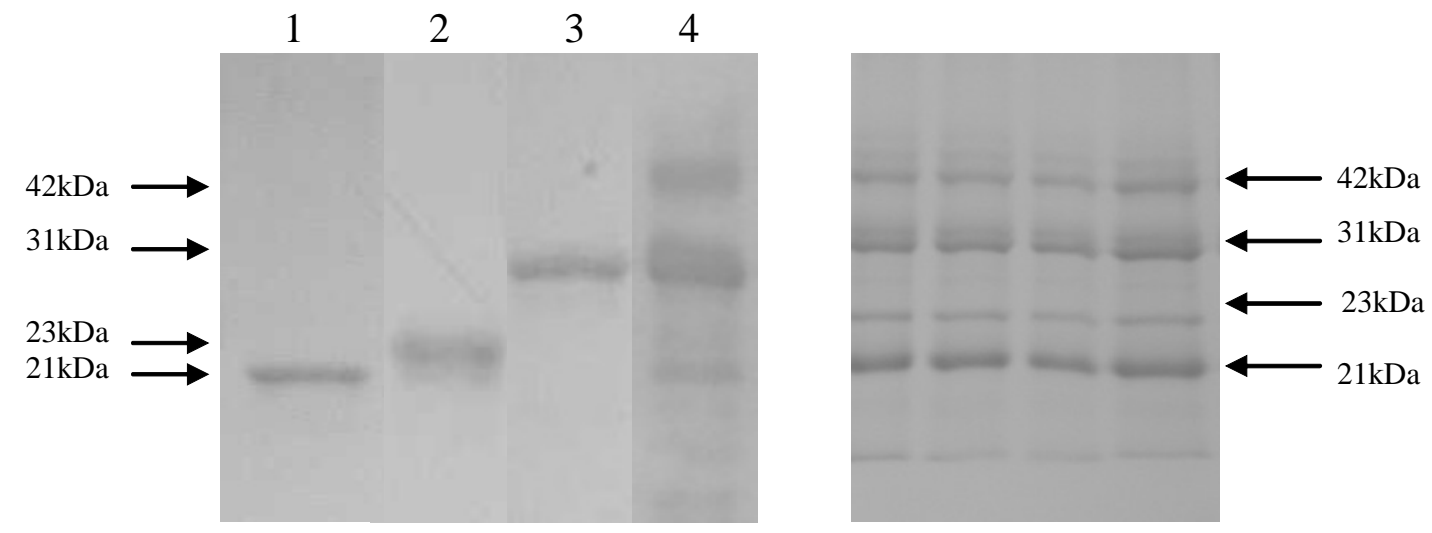

FIGURA 2 - Western blot (à esquerda) mostrando reação do anticorpo anti-21 kDa contra a proteína 21 kDa (coluna 1); anticorpo anti-23 kDa contra proteína $23 \mathrm{kDa}$ (coluna 2); anticorpo anti-31 kDa contra proteína $31 \mathrm{kDa}$ (coluna 3); anticorpo anti-42 kDa contra proteína $42 \mathrm{kDa}$ (coluna 4). Cada coluna contêm aproximadamente $7 \mu \mathrm{g}$ de proteína total (extraída de plantas afetadas pela anomalia declínio dos citros). À direita, gel SDS-PAGE 12,5\%, indicando posições relativas das proteínas.

\section{REFERÊNCIAS BIBLIOGRÁFICAS}

ALBRIGO, L. G.; YOUNG, R. H. Phloem zinc accumulation in citrus trees affected with blight. HortScience, Alexandria, v. 16, n. 2, p. 158-160, Apr. 1981.

BERETTA, M. L. G.; LEFEVRE, A. F. V. Declínio: resistência de variedades e pesquisas recentes. Laranja, Cordeirópolis, v. 7, n. 1, p. 71-86, 1986.

BERETTA, M. J. G.; ROSSETTI, V. Declínio de plantas cítricas. In: SIMPÓSIO DE CITRICULTURA, 3., 1988, Jaboticabal. Anais... Jaboticabal: [s.n.], 1988. p. 137-148.

BERETTA, M. J. G.; ROSSETTI, V. Declínio dos citros: uma doença transmissível. In: SEMINÁRIO INTERNACIONAL SOBRE PORTA-ENXERTOS DE CITROS, 1990. Anais... [S.1.: s.n.], 1990. p. 211-221.

BRADFORD, M. M. A rapid and sensitive method for the quantification of microgram quantities of protein utilizing the principle of protein-dye binding. Analytical Biochemistry, New York, v. 72, p. 248-254, 1976.

BRLANSKY, R. H.; TIMER, L. W.; LEE, R. F.; GRAHAM, J. H. Relationnsship of xylem plugging to reduce water uptake and symptom development in citrus trees with blight and blight-like declines. Phytopathology, Saint Paul, v. 74, n. 11, p. 1325-1328, Nov. 1984.
COSTA, A. S.; MÜLLER, G. W.; GUIRADO, N. Contribuições do Instituto Agronômico de Campinas - IAC na área das viroses e moléstias semelhantes dos citros. Brasília, DF: MCT/SECAV, 1998. 75 p. (Contribuições Brasileiras à Ciência e à Tecnologia, 1).

GIROTO, E. J. Correlações de nutrientes em tecidos de laranjeiras (Citrus sinensis (L.) Osbeck cv. Valência) e o declínio dos citros. 1990. 77 f. Tese (Doutorado em Fitotecnia) - Escola Superior de Agricultura de Lavras, Lavras, 1990.

LEE, R. F.; MARAIS, L. J.; TIMMER, L. W.; GRAHAN, J. $\mathrm{H}$. Syringe injection of water into the trunk: a rapid diagnostic test for citrus blight. Plant Disease, Saint Paul, v. 68, n. 6, p. 511-513, June 1984.

PAIVA, L. V. Alterações protéicas e nutricionais em tecidos de plantas afetadas pelo declínio dos citros. $1993.76 \mathrm{f}$. Dissertação (Mestrado em fitotecnia) - Escola Superior de Agricultura de Lavras, Lavras, 1993.

TAVARES, E. D. Avaliação do estado nutricional da laranjeira (Citrus sinensis (L.) Osbeck) cv. Valência com o Declínio dos citros. 1987. 64 f. Dissertação (Mestrado em fitotenia) Escola Superior de Agricultura de Lavras, Lavras, 1987.

TAYLOR, K. C.; ALBRIGO, L. G.; CHASE, C. D. Zinc complexation in the phloem of blight-affected citrus. Journal of the American Society for Horticultural Science, Alexandria, v. 113, n. 3, p. 407-411, 1988. 